\title{
IMPACT OF THE INDUSTRY 4.0 ON SMART CITY DEVELOPMENT
}

\author{
UDC: 711.45:004.738.5 \\ Review Paper \\ Milan POPOVIĆ ${ }^{1 *}$, Borko RAJOVIĆ ${ }^{2}$ \\ ${ }^{1}$ University in Priština, 38220 Kosovska Mitrovica, Filipa Višnjića bb, Republic of Serbia \\ E-mail: popovicmilan184@gmail.com \\ ${ }^{2}$ Tyumen State University, 625003 Tyumen, Volodarskogo Street, The Russian Federation \\ Paper received: 07.04.2021; Paper accepted: 17.04.2021
}

\begin{abstract}
The focus of this paper is on examination of the impact of the Industry 4.0 on smart city development and changes in society due to the diffusion of innovations and modern technologies in all segments of living. From the preconditions for the beginning of the Industry 4.0, followed by the most important achievement that marked it, to the way changes are manifested due to the wide use of smart devices and software, the paper provides a clear overview of effects achieved over the past few decades of technological progress. Furthermore, based on the data available in the current and relevant literature, the role of the Industry 4.0 in the development of smart cities is studied, and the most important elements of it that support smart city development are determined. In this way, conditions are created for an extensive analysis of the motives, factors and forms of smart city development, with priority given to the social dimension of smart solutions and their implementation in everyday living. After having a complete insight into the features of smart cities and key elements of development, an overview of perspectives and expectations in the field of improving the quality of living in the urban environment by implementation of smart solutions, i.e. devices, software and applications, is provided. Finally, based on previously conducted analyses, conclusions are made on further courses of action in the field of smart city development.
\end{abstract}

Keywords: Industry 4.0; Smart cities; Smart solutions; Sustainable development.

\section{INTRODUCTION}

As we examine the history of humankind, since the first people until the contemporary men, we can come to a conclusion that the betterment of society is largely based on advancement and refinement of technology (Drucker, 2010). Whether we consider the discovery of the wheel, the invention of new machines and industrial processes, or even the use of artificial intelligence (AI), it is clear that technological development has enabled humans to reach a higher level of awareness, work and organisation within a community (Etmanski, 2015; Flasinski, 2016). The first three industrial revolutions led to numerous changes in society and economy, from increased use of machines and development of urban environments, followed by industrialisation and the improvement of the standard of living, and going towards automation and the reduced role of human labour in the manufacturing process (Murray, 2017). However, today we are witnessing the Industry 4.0, a revolution which is radically changing the world as we know it. Virtually, all spheres of society are affected by the development of modern technology, both positively and negatively, forcing people to adapt to new living and working conditions (Davila \& Epstein, 2006). Therefore, the ability to adapt quickly and efficiently has become one of the key factors of survival in challenging and turbulent times (Rogers, 2003).

Cities are also going through a transformation caused by technological advancement, but the path from tribal communities to metropolises of today has been long and has not been easy at all (Christensen et al., 2019). The founding of the first cities is attributed to the rise of agriculture and commerce, and it is clear that meeting basic needs and economic motives were the main cause of their existence. As centuries went by, so did cities develop, expand and change their roles in a community's living. The achievements of the Ancient Greece and the Ancient Rome are still a 
source of admiration all over the world, but even their people, expert builders and innovators, could not fathom living in a modern city which can be self-governing. This specifically has to do with smart cities, which came to exist because of rapid technological development and the profound impact of the Industry 4.0 on everyday activities, as well as on time management and space planning. Thus, determining the conditions that brought about the existence of smart cities, as well as examining the changes in the way of living and environment along with pros and cons of smart city development, we create the basis for efficient smart city governance, creation of new smart cities and implementation of smart solutions in order to improve city living (Satell, 2017; Saldanha, 2019).

\section{The Industry 4.0}

It is difficult to pinpoint the beginning of the Industry 4.0 development, since it was not set in motion by any isolated event or discovery, but what we know for certain is that it is changing the ways in which people live, work and communicate with each other (Schwab, 2016). Knowing the features of the Industry 4.0, which is a relatively new concept in scientific and business circles, is an imperative to successful advancement of society and global economy, as well as successful adaptation to living in this technological era (Degraff \& Degraff, 2017). The wide use of information and communication (ICT) systems, digitalisation of industrial and management processes, development of robots, AI and the Internet of Things - all of them are innovations which have made possible the occurrence of the Industry 4.0 and the changes which lead our society towards a future based on the application of smart devices in our everyday lives (Dodevska et al., 2018). However, it is debatable whether the dependence on technology and smart devices is a benefit or a drawback of the Industry 4.0; nevertheless, it is evident that the Industry 4.0 has been the cause of a significant economic growth within the past few years, as well the cause of increased management process automation, interpersonal communication efficiency and awareness of the importance of sustainable energy and economy (Springer Publishing Company, 2014; Skilton, 2018).

The Industry 4.0 brings about something that no other Industrial Revolution has - a connection between man and technology, i.e. between man and smart devices, which gives rise to better control and management of time, activities and living in general (Venuvinod, 2010c). The lines between man and computers are gradually being erased and information is exchanged rapidly between them, thus creating a need for cooperation between a living being and a machine in order to improve standards, working conditions and industrial processes (Venuvinod, 2010a). In such an environment, support must be mutual between people and ICT systems, i.e. decision-making is based on data provided by technology, but simultaneously, smart systems which lead to autonomy and governance without the influence of the human factor are created (Bonner, 2017; Marr, 2016). Therefore, the Industry 4.0 is a modern phenomenon witnessed by our generation, through many imperceptible, but also impactful and fundamental social changes, as well as through significant technological discoveries such as blockchain technology, genetic programming, the development of nanotechnology, AI and 5G network, the use of 3D printers, drones and robots, etc. (United Nations Conference on Trade and Development [UNCTAD], 2021).

The complexity of the Industry 4.0 is reflected by its impact on economy, society, politics, education, culture, quality of living and general well-being, but it is also reflected by the existence of security threats and by people becoming less independent because of technology (see also Figure 1). On one hand, shopping, going to work, finding necessary information or using public transport have become easier thanks to the development of ICT systems which have facilitated daily activities, and which have led to significant economic growth on a global scale (Venuvinod, 2010b; Schwab, 2016). On the other hand, the contemporary man is exposed to many threats which compromise his security and privacy, which has become a pressing issue in the $21^{\text {st }}$ century, because of increasing presence of people in cyberspace and because of placing business in the domain of internet and cloud technologies (Introbooks, 2018). Additionally, the Industry 4.0 poses a challenge to human labour, which is reflected by technology replacing the human factor frequently, but also by a bigger need for business decentralisation and for promoting work from home (Schwab, 2016; Taboroši et al., 2020). 


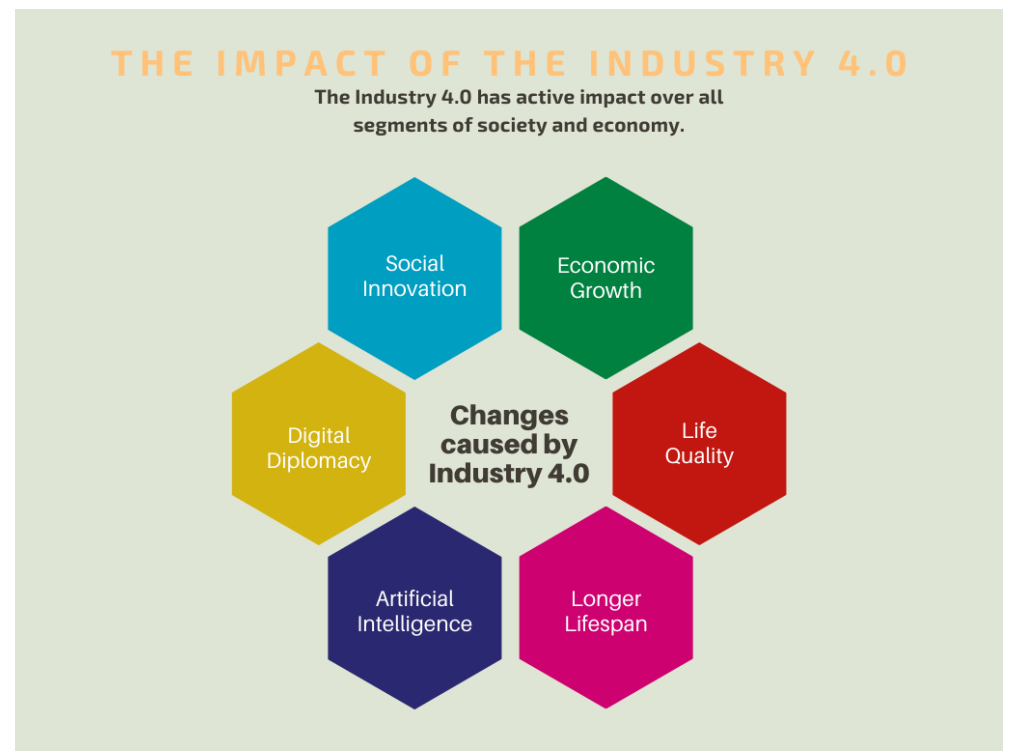

Figure 1: The impact of the Industry 4.0

\section{The Industry 4.0 - Path to Smart Cities}

Development of the Industry 4.0 was followed by numerous innovations in the field of technology, which enable connections between people, organisations and information technology (IT) infrastructure in order to respond to changes in the environment and create better living conditions (Dragičević \& Bošnjak, 2019). All technological discoveries that were made in the last few decades have created a basis for first smart cities which combine human needs with modern technology, equipment and devices in the best way possible, which significantly facilitates the realisation of a broad spectrum of activities, and in turn improves the quality of living in urban environment (Popkova et al., 2019). Today, there is no segment of society or economy that is not affected by the Industry 4.0, so the development of smart cities is a logical outcome of rapid technological progress continuing to change the ways in which people will live and work in the future, not only in an urban environment, but also in rural and other areas (Majstorović \& Mitrović, 2019). Therefore, it is clear that the Industry 4.0 has laid the foundations for smart city development, that is, it has created conditions for connecting scientific and technological discoveries to their implementation in practice, thus initiating changes in society and awareness related to living in smart cities.

A very important element of technological progress is also the entrepreneurial orientation of different scientific studies, which requires researchers to find practical elements of their discoveries that can be useful to most of the population (Todorović \& Todorović, 2019; Zhu, 2016). That is what leads to motives for the development of devices, software and complex ICT systems which support the creation and governance of smart cities. However, every individual discovery and even every single innovation would not be enough for development of smart cities if they existed independently (O'Reilly \& Tushman, 2016). That is exactly why the creation of the Internet of Things through internetworking smart devices and through their automatic operation without human influence is crucial for the development of smart cities (Ali Babar, 2016). Further technological advancement and expansion of the Internet of Things concept led to the Internet of Everything which unifies people, information and devices, and which, through their mutual interaction, increases efficiency, finds new opportunities for growth and improves future living in cities (Ali Babar, 2016; Bloem et al., 2013). Taking that into consideration, we can conclude that existence and enhancement of smart cities could not be possible without the Industry 4.0.

\section{SMART CITY DEVELOPMENT}

Smart cities are urban environments in which modern ICTs are integrated into city operating systems and into everyday living of citizens, which leads to maximum efficiency of living and working in the city, that is, of managing city activities (Ali Babar, 2016; Paulin, 2019). Essentially, the idea of smart cities has already existed for the last few 
decades, but innovations in the field of technology have enabled the application of smart devices in different spheres of society and economy, from healthcare and education, followed by tourism and travel, to waste management and environmental protection (Paulin, 2019). Smart solutions are a way of overcoming problems which modern cities are faced with, principally related to traffic jams, lack of space, high levels of pollution, and increase in urban population. Thus, when city expansion is not possible, the change of approach to city governance and the use of smart applications are the key to creating conditions for good quality of living in the city, which is simultaneously an initial step in the process of the evolutions of cities as we know them into modern, smart cities, based on the latest technological advancements (Satyam \& Calzada, 2017).

According to the UN study conducted in 2018, $55 \%$ of the world population live in urban areas, whereby it is predicted that by $2050,68 \%$ of the population will live in cities. Bearing that in mind, the development of smart cities and of solutions which will allow everything to function normally in big metropolises is the future of living and working in urban environments. However, there is a question as to what makes a city smart - is it technology, people, or both? The answer lies in the integration of human factors and smart devices in order to overcome modern challenges we face daily (Ali Babar, 2016). That is precisely why it is necessary to emphasise social dimension of innovations and of modern technology, given that under no circumstances should we forget the fact that smart devices and applications are developed to improve the standard of living and enable basic needs satisfaction (Saul, 2011; Ali Babar, 2016). Therefore, smart city development mostly depends on technological progress, yet it is also necessary to always stay focused on people and their needs.

A significant threat to smart city development can be an inadequate relationship towards stakeholders, which there are many in this situation (Ali Babar, 2016). Starting from citizens, followed by companies and scientific institutions, and going towards governments and international organisations, the interests of all participants in smart city development vary and it is extremely difficult to direct them towards a common cause (Popović, 2019). Whether it has to do with economic, political, social or some other aspects of smart city development, it is a complex process which requires the allocation of significant human, material and financial resources, as well as making efforts to unify them as a functional whole which will bring expected results. It is important to remark that along with smart city development, there must be certain change in society, which is caused by wider use of smart devices and applications for various everyday activities. Essentially, the socio-economic side of smart city development is often the most prominent, thus it is not surprising that many big and famous companies enter the race to become champions in the domain of smart solutions which will improve living in urban environments.

Since smart city development needs to be comprehensive and fundamental, it reaches all aspects of living and working in the city, so it is necessary to determine basic elements making a certain city smart. Depending on the author and the source, those can be smart governance, smart mobility, smart utilities, smart homes, smart offices, smart building, smart education, smart healthcare, smart environment, smart economy, smart agriculture and many other elements (Ali Babar, 2016; Satyam \& Calzada, 2017). It is almost impossible to select the most important among them, but a need for systematisation of basic elements of smart cities arises with the goal of understanding their features and determining the perspectives of further development. Therefore, in the following text, the key elements of smart cities to change completely the lifestyle of modern generations will be presented, however, certain risks that smart city development carries will be analysed, as well (see also Figure 2). Also, it is important to note that the systematisation and conclusions are based on current and relevant sources, as well as on the analysis of the most recent smart city initiatives.

\section{Smart City Governance}

Smart city governance requires an excellent ICT system network and a high level of training and professionalism of individuals who program and control them. Today, through the implementation of smart solutions, data is collected very quickly and decisions are made in a matter of seconds, eliminating human factor, yet still working in the interests of people and their needs. Modern smart city governance systems encourage transparency and reduce the likelihood of mistakes that may have a negative impact on citizens, thus increasing security and providing autonomy in managing everyday activities in the city (Satyam \& Calzada, 
2017). Through the use of different sensors, computers, software and applications, city traffic is directed, air pollution and environmental pollution are measured, public utilities are provided, security in the city is monitored and many other activities are carried out. Thus, we can conclude that smart city governance entails moving traditional social and political structures into cyberspace, which is definitely a great challenge for most countries, especially for those with an established bureaucratic apparatus (Guglielmo \& Palsule, 2014; Paulin, 2019).

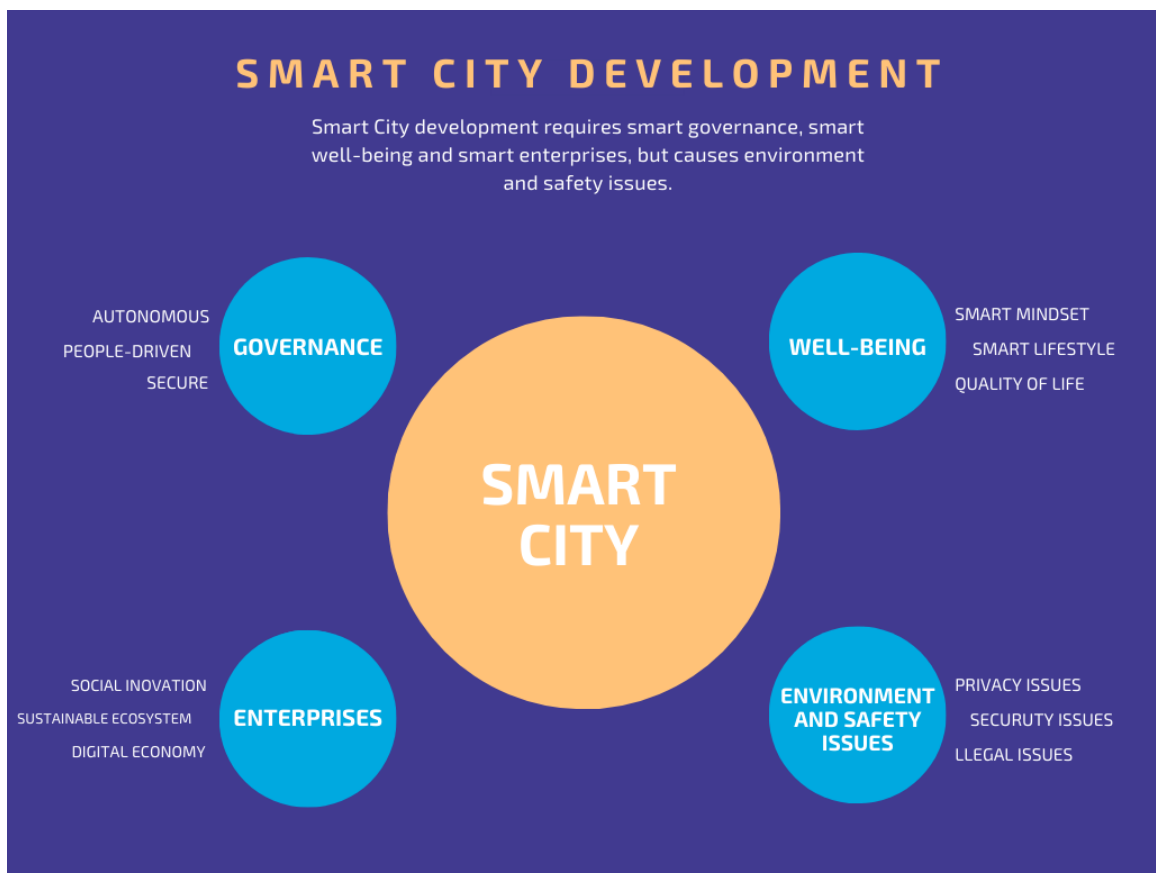

Figure 2: The Elements of Smart Cities Development

In order to solve the abovementioned problem, bureaucracy needs to adapt to modern city living based on independence and freedom of choice, yet is still under the authority of certain systems improving the quality of living in environments. For that to happen, all smart solutions implemented in the process of transition or creation of smart cities must be in alignment with the city features, citizens' needs and public awareness of the importance of smart city development. Therefore, it is of utmost importance to draw a line between people and technology (i.e. smart devices) in the absence of which smart city governance would be inconvenient for citizens, above all in the context of privacy protection and control one has over their own living and decisions. Of course, it should also be borne in mind that city governance solely via smart devices sounds quite utopian, and is not justified for ethical, social and economic reasons. The essence of modern smart city governance systems is actually to increase efficiency in managing city operations and improving living in the urban environment.
Smart solutions in the areas of transport, utilities and public health are cited as one of the most important elements of smart city governance, as well as general well-being of citizens. Smart mobility entails systems that manage public transport, control road safety and supervise the movement of road users, all in order to reduce congestion, pollution and transport costs (Satyam \& Calzada, 2017). Also, smart mobility progress significantly changes the way people use transportation, distances they cross, and vehicles they use (e.g. electric cars) (see also Figure 3). When it comes to utilities and implementation of smart solutions, the focus is on reducing unnecessary waste of water, gas and other natural resources, then on greater use of renewable energy sources, as well as on more efficient waste management, which directly contributes to better environmental protection. Finally, the implementation of smart solutions in the domain of public health is reflected in the use of modern devices and technologies to improve medical procedures in order to extend citizens' life-span, reduce exposure to diseases and provide adequate and timely care (Satyam \& Calzada, 2017). 


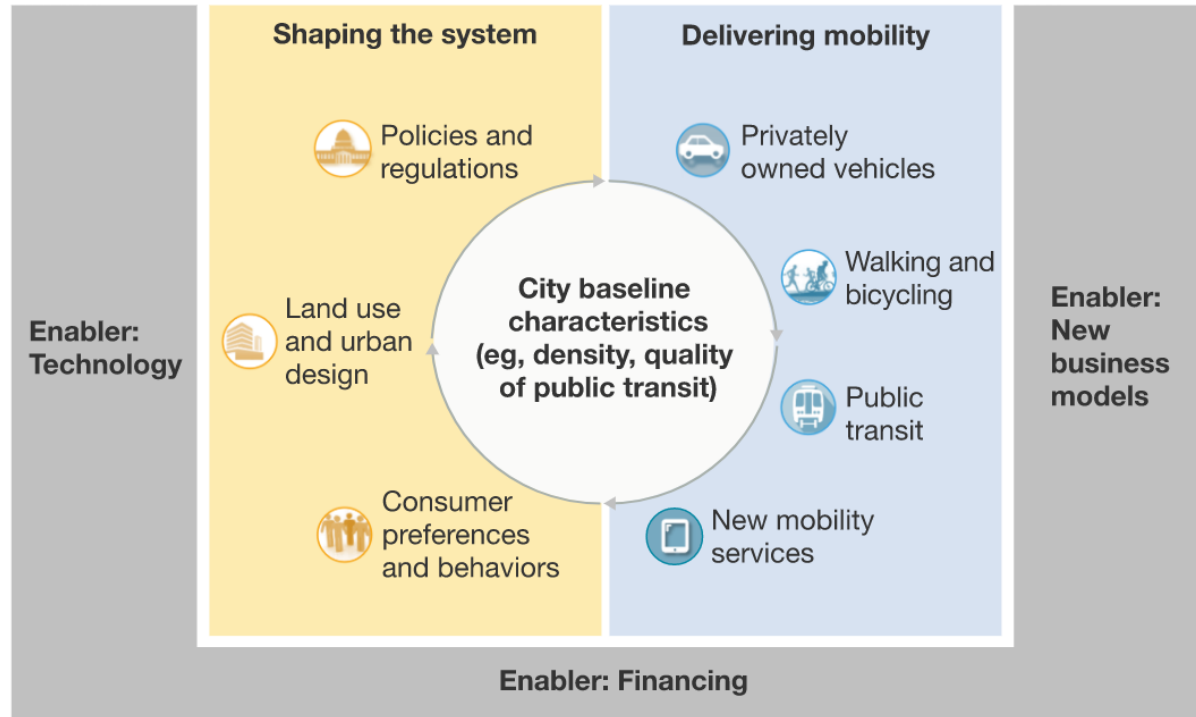

Figure 3: McKinsey`s Framework for Urban Mobility

\section{Smart City Well-Being}

When it comes to smart cities, what is most mentioned is technologies and innovations that have enabled the implementation of smart solutions in order to improve living in an urban environment, but in fact the focus of smart city development are always people and their needs (Henry, 2015). However, preserving the social dimension in a smart environment is challenge in the modern age, as flexibility and adaptation to change had become the key to a successful life and business (Grebić, 2019). The implementation of various smart solutions changes awareness, lifestyle and views on community, and inevitably imposes the need for continuous improvement of people as living beings in order to adjust to new living and working conditions in smart cities. Smart technologies make performing everyday activities easier and simpler, enable time saving, money saving and energy conservation, and contribute to greater real-time information availability and its integration with human needs (Klein, 2016). On one hand, the benefits of smart cities are definitely perceptible, but on the other they simultaneously lead to dependence on smart devices.

Living in smart cities requires smart people, that is, a smart approach to learning and getting to know features of urban environment, which connects people and technology in the best way possible. The relationship between man and technology is interactive - people initiate the creation of new smart solutions, but new smart solutions also initiate social change, which is actually the basis for the successful and promising functioning of smart cities. Smart solutions that are implemented in urban areas - usually different software, applications and devices - have a positive impact on the quality of living and improve living standards of the population because they contribute to solving the current problems that cities face due to population growth (e.g. pollution, congestion, lack of space, etc.). Also, communication, both between people and between people and technology, is becoming more efficient, with the amount of information collected growing by the day, and therefore society in smart cities depends on availability of information in cyberspace and processing it in order to make smart decisions. Therefore, we can conclude that the feedback between technology and people, i.e. citizens, is conditio sine qua non for smart cities.

Our homes are a very important segment of living in smart cities, but so are the offices where people spend most of their day. Today, smart home security systems can control household appliances, adjust temperature or lighting of the room, or monitor what is happening in an apartment or house in real time. The use of various gadgets and devices makes it easier to maintain living space and improves comfort and quality of living in smart cities. When it comes to offices, smart solutions are an extremely important factor of productivity at work, and, therefore, they are increasingly implemented so as to increase employee satisfaction. Smart cities often have entire high-tech districts where companies are oriented towards creating innovations and changes in society through the development of new smart 
solutions. However, modern business conditions have led to an increase in the number of people working from home, further implying the need for integration of workspace and living space (Satyam \& Calzada, 2017; Reese, 2018). Essentially, whether it has to do with offices or homes, smart buildings, smart materials and smart management systems are definitely an indispensable element of good living in smart cities.

In the context of living in smart cities, it is also necessary to point out to the problem in the form of inflexibility and inadequacy of traditional approach to education not supporting smart city development (Satyam \& Calzada, 2017; Seldon \& Abidoye, 2018). Namely, education is the backbone of understanding of living in smart cities and creating change, but conventional education systems undergo the process of transformation and alignment with modern technological advancements slowly and with difficulty, which is especially prevalent in poorer countries (Satyam \& Calzada, 2017; Seldon \& Abidoye, 2018; UNCTAD, 2021). However, the implementation of smart solutions improves education by expanding the scope of study, highlighting the practicality of acquired knowledge, increasing the quality of the process of education, facilitating learning and information exchange, as well as by personalising learning and enabling early development of talent and skills (Satyam \& Calzada, 2017; Reese, 2018; Seldon \& Abidoye, 2018). It is for these reasons that we can view the creation of modern and smart education systems as one of the most key factors of citizens successfully adjusting to a new lifestyle that smart city development leads to (Ostojić et al., 2020).

\section{Smart City Enterprises}

Economic growth over the past few decades has been largely conditioned by technological progress, and therefore the progress of the entire society depends on innovation and efforts of entrepreneurs (Haber, 2016). Social enterprises are a special category in modern business practice that, in addition to realising financial benefits, try to solve certain problems the community grapples with (Aleksić, Bjekić, \& Rodić, 202; 0Seelos \& Mair, 2017). Where public authorities, institutions and companies fail, social enterprises offer smart solutions that enable satisfaction of people's needs and smooth functioning of urban environment (Ali Babar, 2016; Seelos \& Mair, 2017). If they meet the goals for which they were created, that is, if they meet citizens' demands and needs, these enterprises become the backbone of smart city development because they have a positive impact on society through creating changes that lead to improved quality of living and work in the urban environment (Bakator et al., 2018). Therefore, social enterprises best combine the social and economic dimension of technological progress and smart city development, thus ensuring the broad reach and effectiveness of innovative solutions.

Today, many start-up companies strive to exhibit their social dimension in order to draw the attention of the wider population, but due to high competition and turbulent business conditions, they fail. However, we always give advantage to businesses that create change through their actions and enable implementation of smart solutions in everyday living (Skilton, 2018).The importance of developing smart solutions is also indicated by the fact that the most powerful tech companies are constantly racing each other to become the principal innovator that facilitates living of each individual. Accordingly, smart city development provides fertile ground for realization of different ideas and innovations by fledgling start-ups that, by developing smart solutions, disrupt existing conditions in the market and in society (Duening et al., 2015; Ćoćkalo et al., 2020; Seelos \& Mair, 2017). For these reasons, the market for smart devices, software and apps intended for smart cities is on the rise, with its value estimated at 400 billion dollars, while McKinsey \& Company states that the European Union alone has spent more than 77 billion dollars on smart city development.

Smart city enterprises, in addition to implementation of technological solutions with the goal of better city governance and increased comfort, are also seeking to improve industrial processes and enable transition of traditional industries into the sphere of internet and digital technologies. This leads to a decrease in the use of natural resources and encourages the use of renewable energy sources, reduces costs and labour, and results in a decrease in pollution levels and dissatisfaction with environmental protection, which in practice most often manifests itself as the construction of smart factories and implementation of smart production management systems (Satyam \& Calzada, 2017; Seelos \& Mair, 2017). Most business processes are digitalised because of significant environmental changes demanding maximum agility and adaptability, as is the case with the development of different types of software 
collecting customer data, processing it and predicting customer preference (Bloem et. al., 2013; Grebić, 2019). With this in mind, we can conclude that digital transformation of business is the future of enterprises that want to fight for their place in smart cities.

\section{Smart City Environment and Safety Issues}

The reckless attitude towards natural resources that people have had for centuries lead to a series of repercussions, principally in the form of global warming, worsening air and water quality, as well as destruction of flora and fauna. The first three industrial revolutions were based on the extensive use of natural resources in order to achieve economic growth. However, the Industry 4.0 should not pose a problem; on the contrary, it is a solution because, through smart city development and use of smart apps, software and devices, it creates conditions for better control of resource consumption and for monitoring relevant parameters and pollution indicators. Additionally, technological solutions in smart cities enable more efficient waste management, eliminate energy waste, and raise awareness about the importance of environmental protection (Ali Babar, 2016). By constructing smart cities in such a way that they can support environmental protection, we lay the foundations for sustainable development of urban environments in conditions of continuous population growth.

Regarding safety of people in smart cities, what is definitely of primary concern are improvements in terms of safer public transport, large-scale use of closed-circuit television (CCTV) cameras, quicker response in case of accidents, better home security and property protection, better fraud detection, etc. (Satyam \& Calzada, 2017). However, smart city development has a downside raising doubts about justification of technological solutions that are implemented to improve citizens' safety. In that context, a crucial problem occurs, concerning the protection of everybody's freedom and privacy, since the development of technology and internet has led to greater exposure to numerous threats. Location tracking, collection and misuse of personal data, identity theft, use and distribution of photos without permission - all of those are security risks we can encounter in smart cities, but also outside of them, so it is necessary to set a clear limit on usefulness of implementation of such solutions. Of course, data misuse is always possible, but that is why smart cities must give their citizens a true sense of security and trust so that such a community could function seamlessly and survive in the long term.

\section{SMART CITY - PERSPECTIVES AND EXPECTATIONS}

With the United Nations predicting that urban population will grow by 2.5 billion by 2050 , we can expect that over time the importance of smart city and smart solution development leading to a normal, healthy living in urban environment will be increasingly emphasised. Developed countries in Europe, North America and Asia have already begun allocating significant funds for smart city development, but are gradually joined by other, developing countries, meaning a relatively good degree of readiness for change towards a new way of living has been achieved (UNCTAD, 2021). However, not all countries have the same economic and social potentials, which is why technological progress and smart cities also carry a risk of increasing inequality among different social groups, as well as between nations on a global scale. That is why it is necessary to emphasise, repeatedly, the social dimension of smart city development taking time and patience for there to be a positive effect on the entire community and not just on certain advocacy groups, regardless of their motives for smart city development.

Bearing in mind that each city has its own specific management, politics, history and culture, whereby the characteristics and habits of citizens also differ, transformation from a traditional to a modern smart city can be challenging for both the government and the public (Satyam \& Calzada, 2017; Altraide, 2019). The continuation of technological progress in the coming years will certainly bring a number of changes to living in urban environment, but it will also change the role of human factor in the city and impose a new order and a new relationship between people and machines, i.e. smart devices. Indeed, a perfect smart city does not exist and will probably never be built, but what is evident is the need for a moderate combination of technological and social elements of smart city development that will enable a good quality of living supported by technology and not depending on it. Therefore, every subsequent step in smart city development leads society towards higher standards in economic, political, cultural, organisational and social senses, is manifested through the emergence 
of new social norms and structures, through creation of new technologies, markets and needs, and through evident economic growth and improvement of standard of living.

\section{Sustainable Development and Digital Economy}

Smart cities, in addition to having to ensure the implementation of smart solutions to improve living in urban environment, must consider the future of younger generations and not just the current needs of population, which is why, in the last few years, the need for sustainable development that does not jeopardise economic, environmental and social perspectives of future generations (Bogetić et al., 2018; Pati et al., 2020). Due to uneconomical and unjustified exploitation, reserves are no longer as available as they used to be, thus, priority is now given to renewable resources that do not destroy the environment, which directly reduces various forms of pollution and enables better nature conservation (Hargadon, 2015). If smart cities were not sustainable, efficiency of technological solutions would definitely be questionable, because in that case they would not properly contribute to quality of living in urban environment, regardless of certain short-term effects. Therefore, sustainable smart cities are the future of technological development and progress of society, that is, the principal goal every individual should pursue, both in urban and rural areas.

It is evident how important sustainable development is for smart cities because of the fact that in the focus of their development today is also the establishment of a circular economy, which fosters environmental protection, by implementing modern technological solutions in different sectors of economy (Tahirović et al., 2018). In essence, circular economy combines profit-orientation of companies with the need for sustainable development in the best way possible, i.e. through the conservation of natural resources and the environment. Accordingly, new economic sectors and activities that are more or less linked to sustainable development, such as waste management, recycling, reuse of building materials and raw materials and creation of eco-friendly factories, devices and technologies, have been gaining importance lately (Kozhovska, 2018). In this way, circular economy provides a proactive approach to preservation of natural resources and encourages emergence of innovations that enable far more efficient environmental protection. (Patil et. al., 2020). Also, the existence of feedback between circular economy and sustainable development is one of the key factors in the successful functioning of smart cities, implying that in the future circular economy will be an important factor in economic growth and social progress (Venuvinod, 2010c).

Side by side with circular economy is digital economy, a new concept that pays special attention to the impact of innovations and technological progress on economy and economic growth. Namely, the digital economy rests on modern technological solutions that fundamentally change business conditions and force all market participants to transfer business into the digital sphere (Todorović et al., 2018). Whether it has to do with mobile applications enabling quick purchase, data sharing and information verification, or with complex ICT systems that facilitate manufacture, sales and other business processes, digital economy strives to use modern technological discoveries to increase productivity, efficiency and profitability, and therefore is at the core of successful development and progress of smart cities and, thus, of establishment of conditions for development of circular economy. However, for all the advantages of digital economy in smart cities, it should be noted that it changes the role of people in the manufacturing process, often to their detriment (e.g. replacing humans with robots), whereby many companies fail to maintain the pace necessary for survival in the smart city market (Wagner, 2012).

\section{Smart City Initiatives}

Initiatives for smart city development exist around the world, and they first emerged at the beginning of the previous decade, first in the developed countries and then the countries in transition (see also Figure 4). Some initiatives relate to overall development of a smart city, while most focus only on one segment of smart city development, such as mobility, health care, living space, city governance, etc. The aim of the smart city development initiatives is to create conditions for practical implementation of ideas that could improve living in urban environment (Wagner, 2019). In addition to innovation and successful implementation of their own smart solutions, smart city development initiatives must achieve mutual co-operation in order to contribute to the completion of a common mission, i.e. to enable new smart solutions to form a functional whole 
that facilitates living and working in city, as well as of smart city governance. Finally, initiatives for smart city development must also follow the principles of sustainable development, circular and digital economy, and pay special attention to preservation of social dimension of smart city development and application of digital technologies in everyday living.

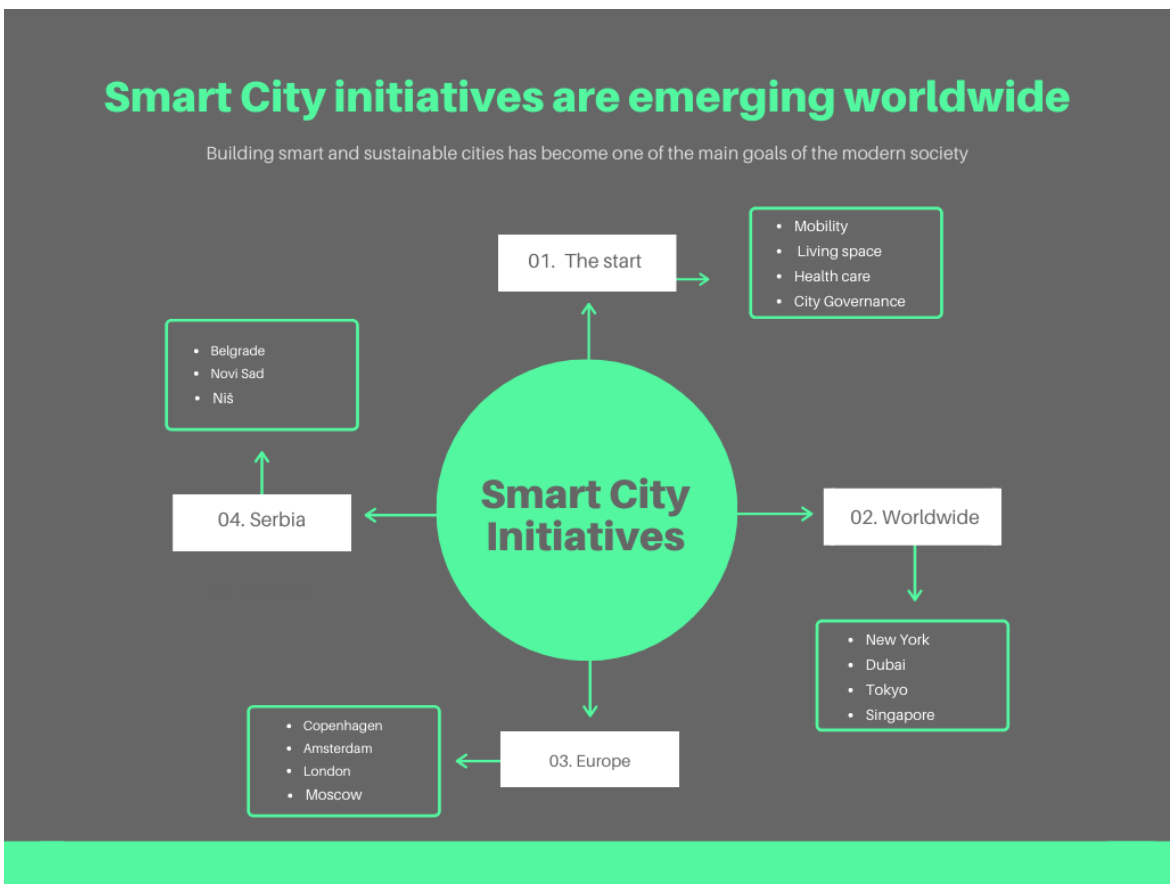

Figure 4: Smart City Initiatives

\section{Smart City Initiatives Worldwide}

Some of the most significant initiatives for smart city development exist in the United States and countries of the Far and Middle East. First of all, the initiative to launch the MetroLab project, a major research on smart city development, came from Washington, directly from the top of American politics (Sarver, 2017). On the other hand, the City of New York has been implementing smart systems for years, which has enabled a 10 percent reduction in congestion, easier access to information and the internet, and more efficient management and collection of utilities. The degree of implementation of smart solutions to increase energy efficiency, strengthen security and improve space planning is at an enviable level in Tokyo. It is closely followed by Singapore, one of the pioneering cities when it comes to implementation of smart solutions in everyday living and transforming traditional cities into modern, smart ones. It is important to note that there has also been an initiative in Dubai to develop smart cities since 2013, and it resulted in the process of intensive digitalisation of business, city governance and realisation of various living activities.

\section{Smart City Initiatives in Europe}

Initiatives for the development of smart cities exist throughout the Old Continent, and are supported by the European Union, namely the European Commission, which is actively working on connecting cities, investors and companies into a single Smart City marketplace. Among Europe's smart cities, a particularly important one is Amsterdam, which has realised over 170 smart solutions implementation projects since 2009 , and, thus, has eliminated problems with floods, traffic congestion and overpopulation. Significant achievements smart city development has also been made by Copenhagen, known for its smart air quality maintenance system, followed by London and Manchester, which focus on solving traffic and pollution problems, as well as Barcelona and Madrid, Spanish cities that implement smart systems to manage city operations. When it comes to Eastern Europe, Moscow is in the lead, boasting the implementation of extremely efficient digital systems that it is developing independently, which makes it one of the most important initiatives for the development of smart cities in Europe. 


\section{Smart City Initiatives in Serbia}

We can safely say that Serbia, as well as other countries in the region, are seriously falling behind countries in Europe, North America and Asia regarding smart city development and implementation of smart solutions in everyday living. The most important initiatives for smart city development come from Belgrade, the capital of Serbia, which has problems with large populations, poor municipal infrastructure and frequent traffic jams. The implementation of smart solutions would certainly improve the quality of living in the capital, but the realisation of such projects is often delayed due to economic and social situation. In addition to Belgrade, Niš and Novi Sad have large prospects for switching to smart solutions, important industrial and educational centres. Also, smart solutions implementation should certainly enter the field of agriculture, one of the most important industries in Serbia, in order to achieve maximum potential of natural resources. However, development of smart cities in Serbia remains uncertain, but efforts do exist, in terms of scientific research, involvement of scientific and business public, as well as organization of various conferences, seminars and panel discussions.

\section{CONCLUSION}

Summing up information, ideas and conclusions that have been presented in this paper, we can confirm with certainty that development of the Industry 4.0 will continue to change and transform living of each individual in urban environment, as well as outside it, that is, in less urban areas. A series of social and economic changes will occur as a logical sequence of events and will enable further progress of society, whereby growth in both social and economic domains will be based on smart technological solutions, which improve living and facilitate completing daily activities. Smart cities are no longer something unknown, they are our reality and our future, thus, in the coming years we can expect a substantial increase in numbers of smart cities in the world, but also an improvement in smart solutions that are implemented in order to manage cities and city operations. Additionally, we can expect increased awareness concerning the importance of sustainable development of smart cities and application of circular economy, which will enable higher efficiency in terms of environmental protection, public health protection and care for the needs of future generations. Therefore, people are always the focus of smart city development, but also the development of principles of smart city sustainability, functionality and efficiency.

In the years ahead, it is estimated that the number of smart city development initiatives will increase, with them having to be enthusiastic, innovative and ready to act well ahead of their time while respecting the social dimension of smart city development. Therefore, although based on technological advancements and performancedriven, the development of smart cities has as a central figure, or a problem, people and their needs and demands that, by implementing smart solutions, it strives to satisfy in order to ensure better living conditions in urban environment. If we study examples of foreign cities and put achievements of the Industry 4.0 to use, numerous social, economic and functional problems in our country could be solved through implementation of smart solutions and building smart cities, which would have a positive impact on improvement of living standards and general well-being of population. However, although the number of smart city development initiatives in Serbia is not yet significant, we can definitely expect that, first large and then smaller cities, in the near future will be transformed into smart and urban environments that best combine modern technology, needs of our citizens and emerging trends in environmental protection.

\section{REFERENCES}

Aleksić, M., Bjekić, R., \& Rodić, M. (2020). Application of corporate social responsibility and companies' environmental performance. Journal of Engineering Management and Competitiveness, $10(2), 81-89$.

Ali Babar, M. (2016). Smart cities: Socio-technical innovation for empowering citizens. Australian Quarterly, 89(4), 18-25.

Altraide, D. (2019). New thinking: From Einstein to artificial intelligence. US: Mango Publishing.

Bakator, M., Đorđević, Đ., Ćoćkalo, D., Nikolić, M., \& Vorkapić, M. (2018). Lean startups with Industry 4.0 technologies: Overcoming the challenges of youth entrepreneurship in Serbia. Journal of Engineering Management and Competitiveness, 8(2), 89-101.

Bloem, J., Van Doorn, M., Duivestein, S., Van Manen, T., \& Van Ommeren, E. (2013). Internet of things. The Netherlands: Sogeti Vint.

Bogetić, S., Đorđević, Đ., Ćoćkalo, D., \& Vorkapić, M. (2018). Corporate social responsibility as a factor of global competitiveness. Journal of Engineering Management and Competitiveness, 8(1), 11-19. 
Bonner, M. (2017, March 2). What is industry 4.0 and what does it mean for my manufacturing. Retrieved from www.viscosity.com

Christensen, C., Ojomo, E., \& Dillon, K. (2019). The prosperity paradox: How innovation can lift nations out of poverty. US: Harper Collins Publishers Inc.

Ćoćkalo, D., Đorđević, D., Bofetić, S., \& Bakator, M. (2020). Youth entrepreneurship development: A review of literature and ten-year research results. Journal of Engineering Management and Competitiveness, 10(2), 151-161.

Davila, T., \&Epstein, M. (2006). Making innovation work: How to manage it, measure it and profit from it. UK: Pearson Education.

Degraff, J., \& Degraff, S. (2017). The innovation code: The creative power of constructive conflict. US: Berret-Koehler Publishers Inc.

Dodevska, Z., Kvrgić, V., \& Štavljanin, V. (2018). Augmented reality and internet of things implementation in projects by using simplified robotic models. European Project Management Journal, 8(2), 27-35.

Dragičević, Z., \& Bošnjak, S. (2019). Harmonizing business and digital enterprise strategy using SOA middle-out and service-based approach. Journal of Engineering Management and Competitiveness, 9(2), 97-112.

Drucker, P. (2010). Innovation and entrepreneurship. US: Harper-Collins E-Books.

Duening, T., Hisrich, R., \& Lechter, M. (2015). Technology entrepreneurship: Taking innovation to the marketplace. UK: Elsevier Inc.

Etmanski, A. (2015). Impact: Six patterns to spread your social innovation. Canada: Author.

Flasinski, M. (2016). Introduction to artificial intelligence. Switzerland: Springer International Publishing AG.

Grebić, B.(2019). Traditional vs agile project management in the service sector. European Project Management Journal, 9(2), 55-63.

Guglielmo, F., \& Palsule, S. (2014). The social leader: Redefining leadershipfor the complex social age. US: Author.

Haber, J. (2016). The business of good: Social entrepreneurship and new bottom line. US: Entrepreneur Media, Inc.

Hargadon, A. (2015). Sustainable innovation. US: Stanford University Press.

Henry, H. (2015). Everyday Innovation. UK: Oak Tree Press.

Introbooks. (2018). Industry 4.0. US: Author.

Klein, K. (2016). Fundraising for social change. US: John Wiley \& Sons, Inc.

Kozhovska, E. (2018). Integration of health, safety and environmnetal principles into industrial project management. European Project Management Journal, 8(1), 33-39.

Majstorovic V. D., \& Mitrovic R. (2019) Industry 4.0 Programs Worldwide. In: Monostori L., Majstorovic V., Hu S., Djurdjanovic D. (eds) Proceedings of the 4th International Conference on the Industry 4.0 Model for Advanced Manufacturing. AMP 2019. Lecture Notes in Mechanical Engineering. Springer, Cham. https://doi.org/10.1007/978-3-030-181802_7.

Marr, B. (2016, June 20). What everyone must know about industry 4.0. Retrieved from www.forbes.com

Murray, A. (2017, November 20). Notes from the fourth industrial revolution. US: Time Magazine.

O'Reilly, C., \&Tushman, M. (2016). Lead and disrupt: How to solve innovators dilemma. US: Stanford University Press.

Ostojić, B., Berić, I., Pavlović, K., \& Pećić, K. (2020). Management education and sustainable development projects. European Project Management Journal, 10(1), 69-77.

Patil, R., Seal, S., \& Ramakrishna, S. (2020). Circular economy, sustainability and business opportunities. The European Business Review, January/February.

Paulin, A. (2019). Smart city governance. The Netherlands: Elsevier Inc.

Popkova, E., Ragulina, Y., \&Bogoviz, A. (2019). Industry 4.0: Industrial revolution of the $21^{\text {st }}$ century. Switzerland: Springer International Publishing AG.

Popović, B. (2019). Product and service reliability estimateon. Journal of Engineering Management and Competitiveness, 9(2), 124-133.

Reese, B. (2018). The fourth age: Smart robots, conscious computers and the future of humanity. US: Atria Books.

Rogers, E. (2003). Diffusion of innovation. 5th ed. US: Simon\&Schuster, Inc.

Saldanha, T. (2019). Why digital transformations fail: The surprising disciplines of how to take off and stay ahead. US: Berret-Koehler Publishers Inc.

Sarver, W. (2017). Smart city: Use cases and development notes. US: Author.

Satell, G. (2017). Mapping innovation: A playbookfor navigating a disruptive age. US: McGraw-Hill Education.

Satyam, A., \& Calzada, I. (2017). The smart city transformations: The revolution of the $21^{\text {st }}$ century. New Delhi: Bloomsbury.

Saul, J. (2011). Social innovation. US: Jossey Bass.

Schwab, K. (2016, January 14). The fourth industrial revolution: What it means and how to respond. Retrieved from www.weforum.org

Seelos, C., \& Mair, J. (2017). Innovation and scaling for impact: How effective social enterprises do it. US: Stanford University Press.

Seldon, A., \& Abidoye, O. (2018). The fourth education revolution. UK: The University of Buckingham Press.

Skilton, M. (2018). The fourth industrial revolution: Responding to the impact of artificial intelligence on business. UK: Palgrave MacMillan.

Springer Publishing Company. (2014). Social innovation and ipmact in nonprofit leadership. US: Author. 
Taboroši, S., Strukan, E., Poštin, J., Konjikušić, M., \& Nikolić, M.(2020). Organizational commitment and trust at work by remote employees. Journal of Engineering Management and Competitiveness, 10(1), 48-60.

Tahirović, T., Naumović, T., Živojinović, L., Bogdanović, Z., \& Despotović-Zrakić, M. (2018). Designing augmented services for e-business:A project management perspective.European Project Management Journal, 8(2), 9-16.

Todorović, M., Toljaga-Nikolić, D., \& Bjelica, D. (2018). People-oriented principles and values of agile project management. European Project Management Journal, 8(2), 3-8. https://doi.org/10.18485/epmj.2018.8.2.1

Todorović, Z. W., Todorović, J. M. (2019). Making engineering departments entrepreneurial: A discussion. Journal of Engineering Management and Competitiveness, 9(1), 60-71.
United Nations Conference on Trade and Development [UNCTAD]. (2021). Technology and innovation report 2021. US: Author.

Venuvinod, P. (2010a). Technology, innovation and entrepreneurship, Part I : My world, my nation. US: Author.

Venuvinod, P. (2010b). Technology, innovation and entrepreneurship, Part II : My firm. US: Author.

Venuvinod, P. (2010c). Technology, innovation and entrepreneurship, Part III : My startup. US: Author.

Wagner, R. (2019). Technologies are not enough to make city smart. European Project Management Journal, 9(1).

Wagner, T. (2012). Creating innovators: The making of young people who will change the world. US: Simon\&Schuster, Inc.

Zhu, P. (2016). Unpuzzling innovation: Mastering innovation management in a structural way. US: Author.

\section{UTICAJ INDUSTRIJE 4.0 NA RAZVOJ PAMETNIH GRADOVA}

Rad se foksuira na ispitivanje uticaja četvrte tehnološke revolucije na razvoj pametnih gradova $i$ stvaranje promena u društvu usled snažnog prodora inovacija i modernih tehnologija u sve segmente života. Počevši od preduslova za početak četvrte tehnološke revolucije, preko najvažnijih dostignuća koja su je obeležila, do načina na koji se manifestuju promene usled široke upotrebe pametnih uređaja i softvera, u radu je dat jasan pregled efekata koji su postignuti u prethodnih nekoliko decenija tehnološkog progresa. Dalje, bazirajući se na podacima dostupnim u aktuelnoj i relevantnoj literaturi, studira se uloga industrije 4.0 u razvoju pametnih gradova, te se određuju njeni najznačajniji elementi koji podržavaju razvoj pametnih gradova. Na taj način se stvaraju uslovi za opsežnu analizu motiva, faktora i oblika razvoja pametnih gradova, pri čemu se prioritet daje socijalnoj dimenziji pametnih rešenja i njihove primene u svakodnevnom životu. Nakon sticanja kompletnog uvida u specifičnosti pametnih gradova i ključnih elemenata razvoja, pruža se pregled perspektiva i očekivanja u oblasti unapređenja kvaliteta života u gradskoj sredini primenom pametnih rešenja, odnosno uređaja, softvera i aplikacija. I na kraju, zasnivajući se na prethodno izvršenim analizama, donose se zaključi o daljim pravcima delovanja u oblasti razvoja pametnih gradova.

Ključne reči: Industrija 4.0; Pametni gradovi; Pametna rešenja; Održivi razvoj. 